\title{
THE INCLUSION AND ACCESS OF SOCIAL HOUSING MOVEMENTS TO

\author{
MINHA CASA MINHA VIDA:
} \\ THE EMERGENCE OF THE ENTIDADES MODALITY
}

\section{INSERÇÃO E ACESSO DOS MOVIMENTOS sociaIs de moradia No PROgRAMA MINHA CASA MINHA VIDA:}

O SURGIMENTO DA MODALIDADE ENTIDADES

Patrícia Maria de Jesus

Universidade Federal do ABC, Programa de Pós-Graduação em Planejamento e Gestão do Território, Santo André, São Paulo, Brasil

\begin{abstract}
A B S T R A C T : In 2009, when the Minha Casa Minha Vida Program was introduced, there was a specific modality contained within its portfolio, which was to be executed by non-profit entities. However, because it was known from the very start that this program had been proposed and structured by those from within the civil construction industry, we decided to undertake an investigation, which could explain the emergence of a modality called Entidades, together with its scope. The present article analyzes and discusses the importance of the advent of this modality, seeking to problematize it from the viewpoint of the insertion and access of a specific group: the social housing movements. The analysis has been based on the literature, legislation and documentation regarding the program, as well as interviews with leaders and empirical research into projects under construction in the city of São Paulo and the metropolitan region.
\end{abstract}

K E Y W O R D S : housing policy; Minha Casa Minha Vida Program; Minha Casa Minha Vida Entidades Program; social housing movements.

R e S U M O : Já em 2009, ano do lançamento do Programa Minha Casa Minha Vida, havia em seu portfólio uma modalidade especifica para ser executada por entidades sem fins de lucro. No entanto, sabendo-se que o Programa foi proposto e estruturado, desde sua origem, por atores do setor da construção civil, empreendemos investigação que nos explicasse o surgimento da modalidade Entidades em seu escopo. $O$ artigo analisa e discute a importância do advento dessa modalidade, buscando problematizá-la do ponto de vista da inserção e do acesso de um grupo específico: os Movimentos Sociais de Moradia. A análise baseia-se em literatura sobre o tema, legislação e documentaçáo sobre o Programa, entrevistas com lideranças e pesquisa empírica em empreendimentos em obra ou em projeto na cidade de São Paulo e sua regiáo metropolitana.

P A L A V R A S - C H A V E : politica habitacional; Programa Minha Casa Minha Vida; Programa Minha Casa Minha Vida Entidades; movimentos sociais de moradia.

DOI: http://dx.doi.org/10.22296/2317-1529.2016v18n1p92 


\section{INTRODUCTION}

The Minha Casa Minha Vida Program (My Home, My Life - also commonly known in its abbreviated form as PMCMV) is the first major program to provide housing at a federal level since the period of the Military Dictatorship (1964-1985), during which around four million homes were built by the now extinct National Housing Bank (BNH).

Substantial public resources are available for financing at all levels (Income Groups 1, 2 and 3) with significant benefits for the priority group (Group 1), using funds from the Federal Budget. For these unprecedented aspects alone, the program justly deserves to be widely studied, debated and assessed. Moreover, for these reasons and beyond, there are other elements that also deem it worthy of attention: during its two phases ${ }^{2}$, the program aimed to build a total of three million housing units, and its third phase was launched on 30/3/2016 with a building target of 2 million homes, and Bill 4960/2016 is pending in Congress. However, given Brazil's deep ongoing political and economic instability, it is impossible to know if the new phase will ever actually take effect ${ }^{3}$.

At the time, the government's official justification for introducing the program was the 2008 financial crisis, which began in the US and originated in real estate sector. There was a fear that Brazil would feel the effects of this crisis, hence the need to create a countercyclical program. In other words, this would be a program that would operate in the opposite direction to the crisis.

While the Brazilian macroeconomic environment in 2009 was moderately favorable, a real estate program would be suitable for this purpose, since it would provide a boost to the construction industry, stimulate the economy and create jobs. Furthermore, it would also reduce the housing shortage in the country, which stood at around seven million housing units, according to the João Pinheiro Foundation.

Nonetheless, much criticism ${ }^{4}$ was levelled at the program: the private sector draining substantial public funds and similarly the privatized nature of production with no social control; non adhering to the housing shortage within the priority group; detachment from the architecture as proposed by the program and the ongoing discussions within the National Housing Plan (in preparation for its introduction); the absence of a land policy contained within its guidelines; the questionable quality of the housing and a fear that the produced projects located on the peripheries would tend to aggravate the socio-spatial segregation within cities (repeating the pattern of past housing programs); and the fact of being interpreted more as a funding program rather than a housing program stricto sensu.

Given this particular context and the well-grounded criticisms, we went in search of inspiration ${ }^{5}$ and support of the program in order to understand its institutional design and consequently, its operation. We then turned to the literature so as to obtain a better understanding of this program as a form of consoliding Brazil's financialization of its housing policy (in a very particular manner) ${ }^{6}$, a process already observed in other Latin American countries, which, in turn, reflected the financialization of the world's economy (in general) ${ }^{7}$.

This article ${ }^{8}$ deals with the improbable incursion of a specific modality in the program destined for non-profit entities, in a conjuncture so impermeable to them, considering all the previously raised aspects. The hypothesis initially outlined was
1 In Phase I of the Program, the Income Groups were determined in acordance with the minimum salary (up to 3, 6 and 10), while in Phase II they were defined with prefixed nominal values (up to $\mathrm{R} \$ 1,600.00 ; \mathrm{R} \$ 3,275.00$; and $R \$ 5.000,00)$. For more information see the Program Manual (Cartilhas e Manuais do Programa), in the References.

2 Phase I began in 2009, during the $2^{\text {nd }}$ term of Luís Inácio Lula da Silva as President, with the aim of building 1 million housing units (Federal Bill $n=11.977$ on 7/7/2009), and Phase 2 began in 2011 during the 1 st term of Dilma Rousseff as President, with the aim of building 2 million housing units (Federal Bill no 12.424 on $16 / 6 / 2011$ ).

3 On 6/5/2016, 13 thousand units were contracted by Minha Casa Minha Vida Entidades throughout the entire country. Days after, there was talk of repealing the law enabling the contracts. On 20/5/2016 the press announced the suspension of the Minha Casa Minha Vida Program. However, on the same day, the Ministry of Cities denied this information.

4 Arantes and Fix (2009); Maricato (2009); Rolnik and Nakano (2009); Rolnik (2010).

5 When we conducted a doctorate internship under the supervision of Prof. Dr. Emílio Pradilla Cobos, at the Universidad Autónoma Metropolitana-Xochimilco/Mexico, in 2013. This internship was financed by the Fundação de Amparo à Pesquisa do Estado de São Paulo (FAPESP).

6 Royer (2009); Shimbo (2010); Fix (2011).

7 Harvey (1989); Chesnais (2005).

8 This text synthesizes the main issues discussed in the doctorate thesis developed by the author. The research received financial support from the Fundação de Amparo à Pesquisa do Estado de São Paulo (FAPESP). 
9 The Residential Leasing Fund. This modalidility is commonly referred to as "PMCMV Construction Company", or "PMCMV Enterprise". that the social housing movements would not be inserted into the Minha Casa Minha Vida Program, since it was created unmindful of the National Housing Plan, in the midst of the National Housing Policy, a topic which this group and other sectors from civil society had discussed untiringly for decades. However, when we became aware of a specific modality, which was to be executed by this segment in its portfolio, this hypothesis became invalidated, and it therefore fell upon us to understand just how this modality had been developed and how it operated.

By analysing projects either under construction or in the planning stages, in the city of São Paulo and the metropolitan region, together with other aspects raised in the current literature, the legislation which established the modality, the dialogue with the social movement leaders, and the follow up at public debates, enabled the Entidades modality to be seen as a set of adaptations of previous federal housing programs and of the Minha Casa Minha Vida Program itself in its modalty as a type of service to Group 1 operated by FAR 9 . It may also be concluded that its existence does not necessarily ensure favorable conditions for the social movements, which fought for its creation, to access the program. We have been able to verify that from its origins through to its execution, the modality was never a consensual process, given the significant differences between this and other modalities in the program; either with regard to its objectives, allocation of resources, treatment in the different institutional spheres and in its execution and operation.

The article is divided into three sections: the first deals with the political aspects of inserting this modality into the program; in the second, we assess the practical aspects of the social housing movements' access to it; and finally, in the third part, we present the empirical aspects of the research that, together with the other aspects raised, assist in discussing the possible gains brought by the modality and its improvement.

\section{INSERTION - THE EMERGENCE OF THE ENTIDADES MODALITY IN THE MINHA CASA MINHA VIDA PROGRAM: SOCIAL HOUSING MOVEMENTS CALL FOR THE ANNOUNCED GOAL}

In order to understand the Entidades (Entities) modality it is necessary to focus on the context in which Minha Casa Minha Vida was created. However, before that, it is important to understand the history of federal housing policies: legacies, accumulations, inspirations, institutional supports; since this would be the only manner with which to move forward on the following questions:

Since this is not a housing program under the auspices of the National Housing Plan, but rather a financing program with financialization characteristics, how is it then possible to establish a modality within its structure intended for non-profit? Assuming that there was no place for the social housing movements in the Minha Casa Minha Vida Program, why were their agendas incorporated so as to create the Entidades modality? What role did this group play in its creation? Did the institution of this modality automatically signify that the social movements would have access 
to the Program? How did they participate in its operationalization? The following section briefly addresses the main issues.

The Minha Casa Minha Vida Entidades Program ${ }^{10}$ (often abbreviated as PMCMV-E) was not formed concurrently with the Minha Casa Minha Vida Program. On the contrary, it came into being through direct pressure from National Entities in the Fight for Housing ${ }^{11}$ with the goal of building 1 million homes under self-management schemes. In other words, it was formulated after Minha Casa Minha Vida ${ }^{12}$.

Our talks with leaders from the four national entities ${ }^{13}$ revealed that shortly before the program was launched, a group of representatives was invited to Brasilia to be formally "presented" to the Minha Casa Minha Vida Program, which was considered "ready". Some of the leaders registered their surprise at the announcement of this proposal since it was not the one that had been agreed under PlanHab (discussions for which took place prior to developing the Program). Consequently, there were some late talks with other sectors of civil society, after proposals for the Program had been formatted by the Civil House and the Ministry of Finance ${ }^{14}$, entrepreneurs from the construction industry and representatives from the real estate sector (CARDOSO; ARAGÃO, 2013;. RIZEK et al, 2015).

While the leaders recognized that the Minha Casa Minha Vida Entidades was only created in order to meet their demands, at the same time they also admitted that the then President Lula and Ministers Dilma Rousseff and Guido Mantega, representatives of a "progressive" government, and who were leading negotiations at the time, were sympathetic to their appeals.

However, although Minha Casa Minha Vida was an unprecedented program, (as discussed in the Introduction) it was not exactly viewed as an innovation by some of these same leaders. They described the initial ideas ${ }^{15}$ of PMCMV as being part of a historical process spanning three decades, of which the most productive developments had been expressed in the SNHIS/FNHIS ${ }^{16}$ within the bounds of the National Housing Policy and the National Housing Plan. However, the reservations and criticisms with which it was met pronounced the program as a "U-turn."

According to Shimbo (2010, p. 93, author's translation), the program was not only interpreted as "nothing new", but rather as something "obvious", predictable, especially given the ongoing conjunctures in the country, especially in the economic and regulatory environments.

Similarly, the Minha Casa Minha Vida Entidades Program was also not construed as unprecedented, instead some leaders considered it an improved version of the Crédito Solidário Program (CSP), which preceded it. This opinion is also shared by such authors as Cardoso, Aragão and Araújo (2011) and Lago (2011).

As a proposal that came after the Minha Casa Minha Vida Program, the Entidades modality was not drawn up in partnership with the concerns expressed by the national entities. It made more sense not only to capitalize on the "heat of the moment" brought by the launch, but also on a federal government program as a "bearing". Thus, the PMCMV-E was created and established as a genuine, although not explicit, reference to the Crédito Solidário Program (the only federal government program that had hitherto been exclusively for non-profit associations and entities).

There is generally a consensus among leaders of the national entities in the fight for housing relating to the development of self-management programs in the federal government, of which the Crédito Solidário Program was a reference point. Although it
10 This modality was officially called the Habitacional Popular Entidades - Minha Casa Minha Vida Program, in accordance with Resolution ํo 141 on 10/6/2009. The present article adopts the nomenclature Minha Casa Minha Vida Entidades Program.

11 CONAM (The National Confederation of Residents Associations), CMP (Central Social Movements), UNMP (Nacional Union of Socia Housing), MNLM (National Movement in the Fight for Housing).

12 The PMCMV was initially created through Provisional Measure no 459 on 25/3/2009 (Converted into Law 11.977 on $7 / 7 / 2009$ ) and the PMCMV-E was created by Resolution no 141 , on 10/06/2009, by the Trustee Council of the Social Development Fund.

13 These were selected for the research due to their past participation in debates favouring the creation of a federal public housing poli$c y$, for being on the Nationa Council of Cities, and for being based and working in the city of São Paulo.

14 And not by the Ministry of Cities, as we would suppose.

15 Ideas regarding the proposal and not the operation, which it later took on.

16 The National Social Housing System/The National Social Housing Fund. 
17 The Social Development Fund.

18 According to Rodrigues (2013), the Crédito Solidário Program is an adaptation of federal financing programs for the states and municipalities.

19 Referring to the experiences of self-management in the city of São Paulo towards the end of the 1980s and the beginning of the 1990s, during Luiza Erundina's administration.

20 Luciana Royer - An interview given on 2/2013. Luciana Royer is currently a professor at the Faculdade de Arquitetura e Urbanismo da Universidade de São Paulo. At the time of the interview however she was interviewed as the Coordinator (contracted) of Technical Assistance and Special Management Programs for the Management of Urban and Rural Development in São Paulo - Caixa Econômica Federal. was always well-regarded for the manner in which it was modelled, it was nonetheless fragile in terms of resource allocation, which therefore justified the emphasis on the increased supply of resources for the Minha Casa Minha Vida Entidades Program, as well as the facility to access them. Another significant difference is the fact that the CSP was only one form of funding, while in the PMCMV-E, besides the financing, there were also numerous subsidies.

In both programs, the source of funding came from the FDS"17. However, "The CSP is able to use deposits from the FDS, and the PMCMV-E is based on resources from the National General Budget transferred to the FDS through Law 11.977 / 2009" (MINEIRO; RODRIGUES, 2012, p. 30, author's translation). This is the same law that instituted the PMCMV, and this addendum is important because, as we have demonstrated, although the PMCMV-E was guided by the CSP, other incorporated rules are seated in the PMCMV. In other words, the PMCMV-E is a "hybrid" program between the Crédito Solidário Program and the Minha Casa Minha Vida Program.

In terms of mortgages, in the CSP, monthly payments were calculated based on the full amount of the mortgage, while the PMCMV-E considers the ability of the beneficiary families to pay. Furthermore, Resolution No 194 on 12/12/2012 adjusted the net value of the initial monthly payment from $10 \%$ to $5 \%$ of the gross monthly family income. The other possibility is a fixed minimum value, which changed from $\mathrm{R} \$ 50.00$ to $\mathrm{R} \$ 25.00$.

Created as an adaptation of the $\mathrm{CSP}^{18}$ within the context of creating the PMCMV, the PMCMV-E in practice has encountered a number of obstacles in being implemented.

I'll tell you one thing. The Minha Casa Minha Vida Entidades Program was bad from birth. The problem goes right back to its origins, because its structure was based on the development programs of the Caixa Econômica Federal. And how do federal government programs work? They are not intended for associations, entities, which have no prior resources. Call it working capital, something like that. And when I say prior, I mean to do... to go through all the approval stages that are required today, which you didn't in Erundina's time ${ }^{19}$, in this way ${ }^{20}$ (verbal information).

By broadening the reflection, we could risk stating that it is its very hybridity that has made it neither one thing nor the other, but rather a third proposal, a third route. This was a "hybrid" program, the success of which was already at risk from the beginning, and exactly because of its very self. Conflicts, obstacles and problems during its formulation may be encountered in equal proportions during its execution, in fact, one arose from the other.

Another aspect related to the origin of PMCMV-E concerns the amount of resources it was allocated, which were proportional to the construction targets that it was set and, for this same reason, were much lower than those directed to the PMCMV.

In Article 18 of Law no 12,424/2011 (which established the second phase of the program), which amended certain aspects of Law $n^{\circ} 11,977 / 2009$ (which instituted the first), the allocation of resources is thus mentioned: 
The Union is authorized to transfer funds to the Residential Leasing Fund - FAR, to the limit of $\mathrm{R} \$ 16,500,000,000.00$ (sixteen billion, five hundred million Reals), and to the Social Development Fund - FDS, to the limit of R\$500,000,000.00 (five hundred million Reals).

Pedro Arantes and Mariana Fix (2009), comment on the model of program at the time of its launch.

A total of $97 \%$ of public subsidies provided by the housing package, with resources from the Union and FGTS, are passed on for the supply and direct production of private construction companies, and only $3 \%$ to non-profit entities, cooperatives and social movements for the production of urban and rural housing through self-management (ARANTES; FIX, 2009, p. 2, author's translation).

The aim of the Minha Casa Minha Vida Entidades Program is to provide affordable housing for those whose gross monthly income does not exceed R $\$ 1,600.00$, organized into residential or mixed cooperatives, associations and other private non-profit entities, aiming at the production and acquisition of new housing. The Program referred to these groups generically as Entidades Organizadoras (Organizing Entities, which literally acts as an Organizer), whether they were social housing movements or private non-profit associations able to prove to the Ministry of Cities their capacity to build homes. ${ }^{21}$

In other words, within the PMCMV-E every housing movement is an Entidade 21 A process called Licensing the Organizations. Organizadora, but not every Entidade Organizadora is a housing movement. This emphasis is important since for decades, the social housing movements have guided and proposed federal housing programs directed towards the priority groups, which they themselves have then executed, and have thus demanded part of the declared building goal of the PMCMV. However, while this demand was met, it culminated in the emergence of a modality that not only serves them, but that also serves other different groups in terms of their goals, ideologies, operating practices and public. This also signifies that the processes described in this article cannot be generalized to other groups, also defined as Entidades Organizadoras.

The target of 60 thousand units announced for the period 2011/2014 was increased in 2014 to 80 thousand units and covers all national urban areas, giving priority to beneficiaries who meet the following requirements: female-headed households, the disabled, the elderly and socially vulnerable groups.

\section{ACCESS - PROCEDURAL ADJUSTMENTS TO MAKE THE MINHA CASA MINHA VIDA ENTIDADES PROGRAM OPERABLE}

Through the analysis of laws, decrees, resolutions, normative instructions, directives as well as our talks with leaders from the four national organizations, we have attempted to identify what we call the "procedural adjustments", which they all proposed, and which were accepted by the Ministry of Cities in order for the modality to become operable, and to ensure that the proposals were approved and/ 
22 Henceforth, we will use the term "Entidade Organizadora" in reference to all groups that belong to this nomenclature within the institutionalization of the PM$\mathrm{CMV}-\mathrm{E}$; and "social housing movements" in reference to the groups whose activities are directly or indirectly linked in the fight for housing and that were investigated during our study.
23 Groups formed through nominations by architects, but also social workers, sociologists and engineers to advise the social movements on the development of urbanistic and architectural projects. These were formed during the 1990s, within the context of the pioneering experiments with social housing projects both with collective task forces and self-management during Luiza Erundina's government in São Paulo. or contracted quicker. The changes and revisions to the rules and regulations of the modality were made possible through countless discussions, meetings, workshops, occupations and acts at the Ministry of Cities and Caixa Econômica Federal.

Below, we analyze three of these adjustments, each of which relates to a specific difficulty encountered by these movements in accessing the Minha Casa Minha Vida Entidades Program: a) access to land, b) the private logic of housing production, and c) the eligibility of families. It should be emphasized that the Federal Government has continued to receive proposals for several other adjustments. However, we believe that restricting the analysis to just three fulfils with our aim of demonstrating the complexity of the relationship between the movements and the official institutional framework to operationalize the Minha Casa Minha Vida Entidades Program.

One was incorporated into the program's first phase in 2009, and the other two in 2012 in the second phase. This signifies that such procedural adjustments were being incorporated while operational. We will present the manner in which the problem was defined, the norm that regulated the adjustment, and its "practical" aspects.

\section{ACCESS TO LAND $\rightarrow$ AdVANCED LAND PuRCHASE}

The problem: One of the characteristics of the PMCMV-E is that adopting the selected proposals only occurred after the project design had been prepared, approved and licensed. This presupposes two things: 1) that the Entidade Organizadora ${ }^{22}$ is already in possession of the land (either purchased with its own funds or having been donated in counterpart by the Municipal Council, for example) and that 2), further to this, it possesses working capital in order to cover the development and licensing stages of the projects with the relevant bodies. These are impractical requirements, both in theory and in practice, since it has always been difficult for the social housing movements to capacitate areas for their projects/ventures.

A further contributing factor to the problem of accessing land was the real estate boom that occurred in Brazil during the years leading up to the launch of the PMCMV. Competing with the construction companies operating in Group 1/ FAR of the PMCMV for land in areas that they had previously neglected, made negotiations between the social movements and the landowners even more delicate. In other words, between the moment the social housing movements and the land owners signed the "purchase and sale option agreement" and the actual moment of completing the purchase, many opportunities were lost because the owners had passed the land over to the construction companies.

Also, the sums of money needed to conduct feasibility studies, reports, advice and the development of the project itself were beyond their possibilities. And so within this context, they requested the Federal Government to use part of the money that funded PMCMV-E for the advanced purchase of land, and to pay for technical consultants ${ }^{23}$ to perform all the necessary procedures for legalizing the land deeds, feasibility studies and project design.

Adjusting the norm: The operational modality of the PMCMV-E, generically baptized by the social housing movements as "Advanced Land Purchase", was officially regulated by Resolution no 143 on 26/11/2009 with the name "Land acquisition, payment for technical assistance and legalization expenses." 
The practice: Achieving this operational modality was a palliative for the social housing movements' complex problem of land acquisition, and was therefore unable to effectively "unlock" the problems of legalizing the target areas of the program. Numerous obstacles still persist, mainly because the areas made viable by the social housing movements are, logically, those derided by the construction companies. Put in another form, land with physical problems (steep slopes, protected areas, springs, suspected contamination), faces difficulties in being approved by the licensing bodies, and in other cases, land with legal problems face obstacles in being registered with the Notary Real Estate Registry.

Furthermore, this modality of the program was also unknown, not only throughout the branches of the CEF, but also in the very grassroots of the social housing movements themselves ${ }^{24}$. In order to resolve this issue, leaders from the four national entities and the CEF sponsored seminars and workshops so as to spread information and aid its operation, particularly in 2012.

In January 2014, Advanced Land Purchase was suspended by the Ministry of Cities, arguing that the contractual limits of this operational modality had already been reached. Rizek et al. (2014, p. 6) interpreted Advanced Land Purchase as giving the entities an advantage. In the specific case of the social housing movements however, we do not share this interpretation. We believe that conquering this instrument was one of the only real possibilities to access land ${ }^{25}$, and not an advantage.

\section{PRIVATE LOgIC IN HOUSING PRODUCTION $\rightarrow$ PJ/PJ}

The problem: When the Entidades modality was introduced, the mortgage agreements were signed individually by the future beneficiary families, while the homes were still under construction. The Entidades Organizadoras were only accepted and regarded as Organizers (in the broad sense of the term) of the families, and were not directly involved in contracting. When there was a need to replace families (either because they withdrew or were excluded or the income limit was exceeded), matters relating to the individual registration of the property, and in the case of replacement - transfer to another family - extra costs were incurred and deadlines extended for analysis. Moreover, for the Notary Real Estate Registries, until the present day, this has been a totally unprecedented problem. The reason they have been unable to solve this problem is most probably because they have always been used to dealing with construction companies, developers and the like, who turn properties that they will build into "real estate development" and sell them to the families. In the case of social housing movements (in which the logic is not the sale of ready-built properties), however, the Notaries have not registered the properties alleging technical impossibilities, which has eventually overturned the proposals.

Faced with this impasse, the social housing movements proposed that they should figure as temporary contractors for the projects, and that these would be signed at the end of the construction by the beneficiary families. Thus, the proposals would be individualized a posteriori. Hence, the mortgage would be drawn up between two legal entities - the Caixa Econômica Federal and the Entidades Organizadoras - not between one legal entity (Caixa Econômica Federal) and individuals (future beneficiary families).

Adjusting the norm: This operational modality, commonly known as "PJ/PJ"26
24 See Rodrigues (2013).

25 Another possibility wouId be land donations from municipal, state or federal governments.

26 Pessoa Jurídica/Pessoa Jurídica - which refers the tax status of the legal entities. 
27 The comments regarding this resolution are based on the note "What changes with the new Resolution from the Ministry of Cities in the Minha Casa Minha Vida Entidades Program", drawn up by the legal department at $\mathrm{UMM} / \mathrm{SP}$, available at http://www.unmp.org.br. Accessed in: August/2012.

28 The term "demand" refers to the applicants of the project. We adopt this term rather than "applicants" because that is how they are treated by those involved in the process.

29 Pronouncement by the then Housing Secretary, Inês Magalhães, on numerous occasions at debates and pblic activities regarding this theme.

30 Interministerial Regulation № 96, from the 30th March 2016. More information in Bill № 4960/2016. was regulated by Resolution No 190 on 7/8/2012 27 with the name "Direct contracting with the Entidade Organizadora as a temporary stand-in for the beneficiaries, linked to a future contract with the final beneficiaries".

In order for this resolution to be approved, together with calls for the "negotiating table", there were two simultaneous occupations - one at the CEF's headquarters in both São Paulo and in Brasilia on 17/4/2012, and the other at the Ministry of Cities, which took place on 7/8/2012 (the exact date on which the resolution was signed and published).

The pratice: Changes to this Resolution have reduced the bureaucracy of the projects and provided greater security for families, as well as recognizing the social housing movements, not only in acting as representatives of the families, but also as agents for the project.

\section{ELIGIBILITY FOR FAMILIES $\rightarrow$ ANTICIPATING FAMILY ELIGIBILITY}

The problem: Resolutions $\mathrm{n}^{\circ} 182$ and 183 describe three situations in which replacement families for contracted projects may be permitted: the interested family cancels their purchase, the Entidade Organizadora decides to exclude the family, or the income limit is exceeded. With an increase in the national minimum salary over recent years, many families initially established as demand ${ }^{28}$ by the social housing movements (before the project contract) were excluded from the process because they exceeded the $\mathrm{R} \$ 1,600.00$, which was the limit at the time of making the contract with the CEF. The slowness involved in signing the selected proposal contracts also contributed to this fact. We believe that this problem is significantly greater in the Southeastern and Southern states of the country, where although incomes are higher, so is the cost of living. It should be remembered that establishing the value of $R \$ 1,600.00$ as a criterion to access the Program is a national rule. A fixed nominal rate of $R \$ 1,600.00$ instead of three minimum salaries was changed when PMCMV-E 2 was launched, within the launch of PMCMV 2, because this amount is the criterion for the entire Group 1, whether it is the PMCMV- E operated by the FDS, or whether it was the modality of the program operated by FAR.

The social housing movements initially unsuccessfully, called for the return of the minimum salary as a reference, suggesting that at least a certain number of families would be able to exceed the $\mathrm{R} \$ 1,600.00$ limit by $20 \%$. Thus, a proposal was drawn up in order to create an intermediate group, "Group 1/2" - situated between Group 1 (with a ceiling of $R \$ 1,600.00$ ) and Group 2 (with a ceiling of $R \$ 3,275.00$ ).

The Federal Government ${ }^{29}$ argued that maintaining this limit signified that the housing shortage would be concentrated into Group 1, and that this ensures that the program reaches the families of which it is composed. In the third phase of the program, launched on 30/3/2016, in addition to changing the goals, the values of the installments, and the mortgage limits, etc., "Group $1^{1 / 2}$ ", was also included, under the following terms:

Art. 2. The operations referred to in Art. 1 are designed to cater for families with a monthly gross income of up to $\mathrm{R} \$ 1,800.00$ (one thousand, eight hundred Reals), allowing up to R\$2,350.00 (two thousand, three hundred and fifty Reals) for up to $10 \%$ (ten percent) of the families attended by each project $\left[\ldots . .{ }^{30}\right.$ 
Adjustment of the norm: The social housing movements proposed that families should be eliglible for contracted projects while still in the construction stage, and so as to ensure their permanence until completion of the project, the criterion for replacing families who exceeded the income limits was removed from Resolution $\mathrm{n}^{\circ}$ 183. This addendum is in Resolutions no 190, 193 and 194 in the articles regulating the operational modality "Contracting the entity as a replacement for future residents until the construction is completed, thus ensuring eligibility of the demand".

The practice: This measure, even being palliative, managed to solve the constitutional problem of the social housing movements' demand. Especially since, "losing it" throughout the process, as well as being perverse, considering all the political gains achieved by the social housing movements and their grassroots, would be a further bureaucratic burden, regarding the procedure of replacing families.

Thusfar, we have seen how the Entidades modiality of the Minha Casa Minha Vida Program was directed, suggested, designed and "adjusted". Moreover, despite being passed through a government that was more aligned to the aims of the popular movements, its path was nonetheless never peaceful or free from disputes and conflicts. Hurdles recognized by the Ministry of Cities:

[...] we are aware that the design of this program increasingly needs to be improved so that it is able to face up to the possibilities and difficulties and challenges involved in the housing issue... that the social movements produce housing in a country like ours, with institutional and legal difficulties is to recognize the actors in civil society who implement public policies. It is very clear to us at the Ministry of Cities that the distrust, which exists is a misconception. We reaffirm every day that for us the social housing movements are not only legitimate actors, but also play a key role for us to implement our housing policy. I think that this, which we've proved at every moment, has changed a normative. ${ }^{31}$ (Verbal information)

\section{OPERATIONALIZATION AND SPATIAL DISTRIBUTION OF THE MINHA CASA MINHA VIDA ENTIDADES PROGRAM IN SÃO PAULO AND METROPOLITAN REGION}

During the research, we observed that the construction work contained in most of the proposals selected and approved by the Ministry of Cities and the CEF in 2009 (the year the program was launched) were not initiated before the first half of $2014^{32}$.

Therefore, analysing contracted projects (whether under construction or not) in order to proceed to an empirical analysis did not invalidate our analytical process. On the contrary, many more new elements were engendered as we arrived at part of the answer to the question we were pursuing: How do the social housing movements access the Minha Casa Minha Vida Program?

The number of proposals contracted by the Minha Casa Minha Vida Entidades Program in the state of São Paulo is 44 projects, only 4 of which are not located in the city of São Paulo and the metropolitan region. There is one project in the municipality of Santos, one in Campinas and two in Sáo Joáo da Boa Vista. The remaining 40 contracts are concentrated in São Paulo and the metropolitan region.
31 Inês Magalhães, the then Secretary for National Housing on the occasion of the Seminário Programa Minha Casa Minha Vida II - with a partnership between Federal and State Governments on $6 / 6 / 2012$ in the Legislativ Assembly for the State of São Paulo.

32 An exception was made for projects migrating from the Crédito Solidário Program to the Minha Casa Minha Vida Entidades Program, for which contruction work had either been concluded or was close to construction on the said date. 
33 In 2014 and 2015 new contracts for the PMCMV (all Groups) were suspended.
34 When the same plot of land was divided into two or more lots for technical or legal reasons or a partnership between Entidades Organizadoras.
For the purposes of this text, the number of contracts does not necessarily signify the equivalent number of developments. This is due to two main reasons: the first concerns the two contracting stages, since the first contract implies advanced land purchase and the second contract approval of the construction work and the consequent release of funds in order to begin, a procedure only made possible once all approval stages have been completed by the municipal and state agencies. For this reason, the Management Report of the Caixa Econômica Federal (official source of data), with a time limit of December $2013^{33}$, lists all contracts (in the two abovementioned stages) until that point, thus presenting us with the task of interpreting them so as to measure the number of developments.

Thus, for all 40 projects contracted in São Paulo and the metropolitan area (considering these two stages), we have counted $\mathbf{2 6}$ developments. In addition, we have taken into account the fact that cases with two or more adjoining lots, formed of two or more contracts, were seen as the same development when coordinated by the same Entidade Organizadora. On the other hand, there are cases with two or more lots that are formed of two or more contracts, but which are coordinated by different Entidades Organizadoras. These were also interpreted as a single development ${ }^{34}$.

This detail regarding the limit of houses per project is well defined in the rules of the program:

In the exceptional case of forming a contract with the Entidade Organizadora (non-domestic), it is also possible to authorize: a contract for more than one project by an $E n$ tidade Organizadora, limited to three (3); and a contract with more than one Entidade Organizadora in the same project/proposal, limited to three (3) entities. (CAIXA ECONÔMICA FEDERAL, s/d).

With regard to the links with the four national housing entities, we observed from the data analysis that there is a significant number of projects coordinated by the social housing movements that have no links with the four national housing entities (CONAM, CMP, UNMP and MNLM).

We analyzed nine developments: one coordinated by a movement afilliated to CONAM, one coordinated by a movement afilliated to MNLM and seven coordinated by movements afilliated to UNMP.

Other criteria employed during the analysis were: projects in different stages of approval and/or construction work, different construction schemes (self-management or global construction contract), different types of construction (houses or apartments), different locations in the city of São Paulo and different municipalities within the metropolitan area. We have also considered the proportion of the financial counterparts from other federal entities in the project, as well as the Advanced Land Purchase instrument and migration from the Crédito Solidário Program to the Minha Casa Minha Vida Entidades Program.

Of the nine projects analyzed, seven opted for the self-management building scheme and two for the global construction contracts. However, it should be remembered that self-management is not only restricted to the manner of building. Above all, it is the ideology that justifies the existence of the Entidades modality. However, our fieldwork has revealed that neither the construction scheme nor the ideology are necessarily approved of by the social movements that have opted for them. 
For some leaders, the construction scheme and the ideology are extemporaneous, since the socio-economic context of this decade is significantly different from that of thirty years ago, when projects were only feasible with labour provided by collective task forces.

We have encountered different ways of understanding and embarking on selfmanagement: some projects are still undertaken with collective task forces (a small percentage); in others, self-management signifies dispensing with the task force, but not the participation of families in the decision-making processes, such as developing the architectural design, the budget and choice of materials and suppliers, paperwork, policy-linked activities, etc. In projects where the construction scheme involves a global construction contract where small or medium-sized construction companies are contracted to fully manage the work, while the movements are left to manage the federal government resources and specify the families.

Both cases count on the essential work of technical consultants ${ }^{35}$, hired by the social movements with resources from the program to provide advisory services for the projects. They are also in favour of or against self-management, thus the moment of hiring either one or another technical consultant is also the time to opt for technical questions, as well as political and ideological.

The following maps represent the projects of the Minha Casa Minha Vida Entidades Program in the city of São Paulo and the metropolitan region. Map 1 presents the location, where there is a clear focus in districts located on the east side of the city of Sáo Paulo and a conurbation of metropolitan municipalities such as Itaquaquecetuba, Guarulhos, Mauá and Diadema. This same map also demonstrates the projects selected for examination, and which are located in the east, south and north-west of the city, and the metropolitan municipalities of Guarulhos, Suzano and Taboão da Serra.

Map 1: Locations of the projects within the Minha Casa Minha Vida Entidades Program in the city of Sáo Paulo and the metropolitan region

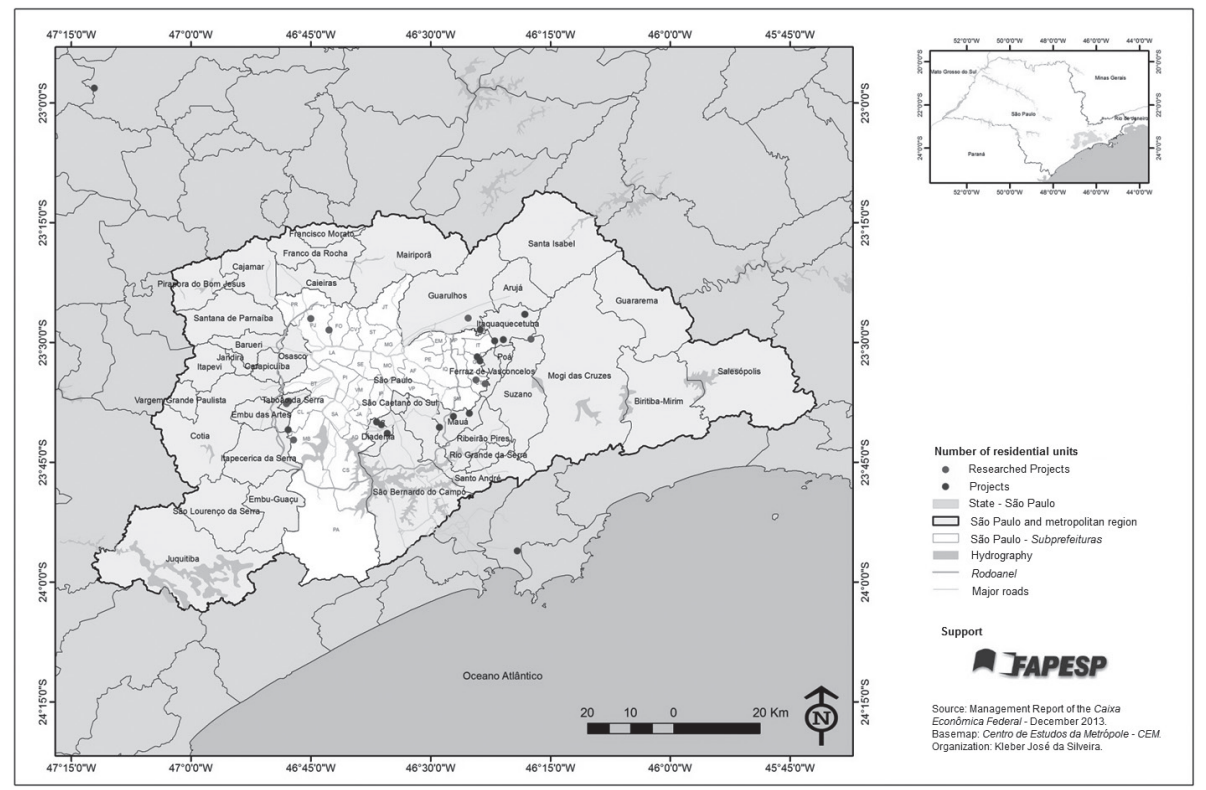


36 Strategic Master Plan for the city of São Paulo. Lei no 16.050 , on $31^{\text {st }}$ July 2014
Map 2 depicts the projects by the number of residential units. It may be observed that the more peripheral projects contain a greater number of housing units. Throughout the research, this unequivocal finding was explained by our interlocutors as optimization between the demand and the cost of land. In other words, the land, although located on the outskirts of the city, was very expensive, and hence could not be used for building only a few units. It is clear that the rationale here, although legitimate (in terms of demand) is the same as that of the market, i.e. build more to offset the costs. It is also for this very same reason that the proposed projects are for apartment blocks. Land with projects containing fewer housing units, as is the case of Suzano, with 80 single-family residential units, were much less expensive.

However, it should be stressed that there are other cases of projects with fewer housing units that are unrelated to the cost of land. One of the projects studied for the research, for example, is located in an area of ZEIS 4: a Special Zone of Social Interest - glebes or land with no buildings in Protected and Watershed Recovery Areas ${ }^{36}$. In this particular case, the watershed in question is the Guarapiranga Reservoir in the south of São Paulo. Thus, on the total area of $60,000 \mathrm{~m}^{2}$ of land only 192 apartments will be built. However, there are other projects located in other zones where it is permissible to build more housing units on much smaller areas of land.

There is also one project located in the central area of São Paulo, which was under negotiation while conducting this research and was therefore not included on the map. This is a building donated by the Secretariat of State Heritage that is being requalified and will contain 120 units.

Thus, the densification in and around the peripheral regions is not only related to the location of projects, but with a combination of other aspects, such as: the cost of land, prerogatives of municipal zones, public real estate donations.

Map 2: Projects by number of housing units

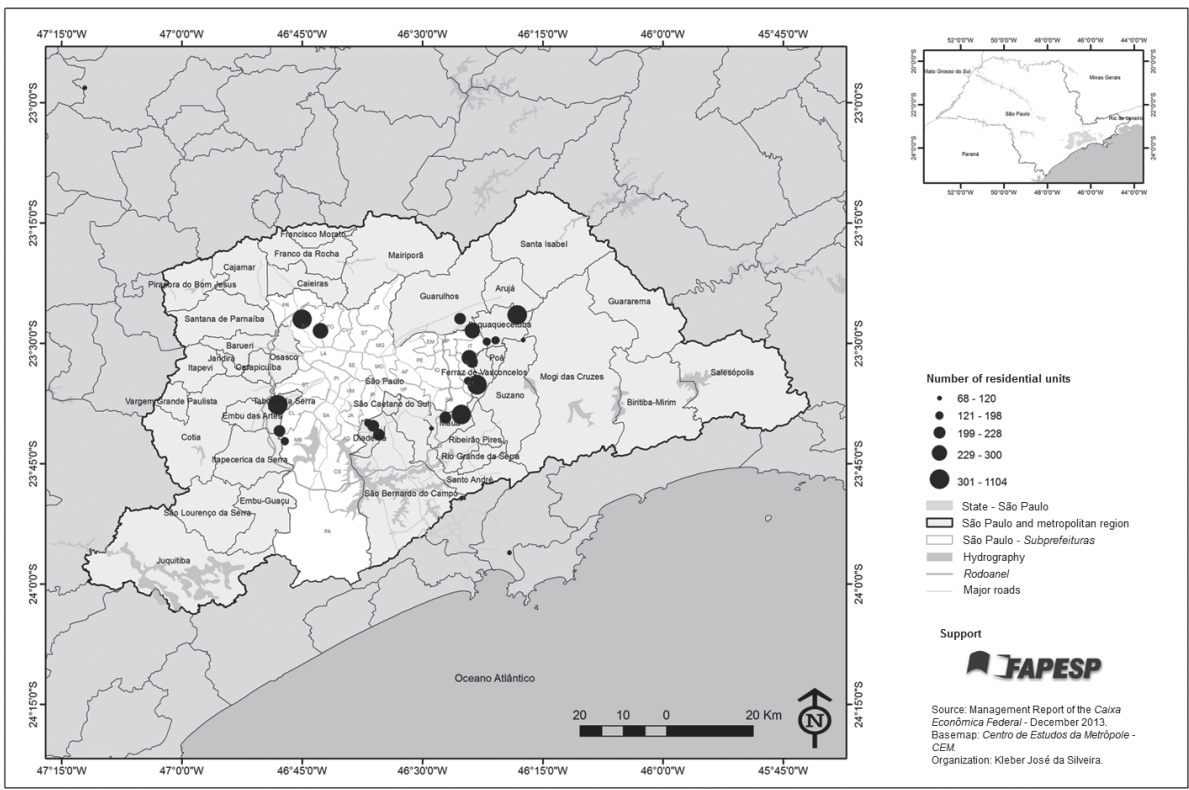




\section{APPROVAL: THE RELATIONSHIP WITH OTHER GOVERNMENT SPHERES}

The interchange with leaders and the field work in the projects under construction or the planning stages revealed some extremely important aspects not envisaged by the document analysis, and the existing literature on the subject. We develop herein an analysis regarding the process of project approval, which is demonstrated as being the greatest difficulty for the operationalization of the Minha Casa Minha Vida Entidades Program. The land issue, although highly complex, was partially resolved by obtaining the Advanced Land Purchase instrument, However, the bureaucratic issue, promptly adjusted within the relevant legislation and regulations, was not sufficient to "unlock" the approvals.

In all cases examined, the approval of projects by federal, state and local agencies is preposterously slow. Not exactly the approvals as such, but rather the time taken.

In the cases analyzed, the process between identifying the land, presenting the Advanced Land Purchase proposal and its effective approval lasted for more than two years, with some cases taking up to four years just to approve the Advanced Land Purchase.

Social housing movements, after the lengthy process of Advanced Land Purchase, need to have the project approved, which basically involves issuing the execution permits, environmental licience, the Fire Department's approval of the project, the utility companies for electricity,water and sanitation and the external and internal infrastructure project. The moment then arrives when they have to come up against their own limits as well as those imposed by the requirements, resistance, ignorance, bureaucracy, prejudice and distrust of the "mid-term body" ${ }^{37}$ represented by officials from the departments and technical departments of the three levels of government involved in the process.

The commitment theoretically established between the three federal entities for implementing the Minha Casa Minha Vida Program in practice is not strong, even less so with regards to one modality of the program, the aims of which are far inferior to those operated by FAR and the FGTS.

Below we have produced two figures so that readers may visualize the process.

Figure 1: Operational flow of the Minha Casa Minha Vida Entidades Program

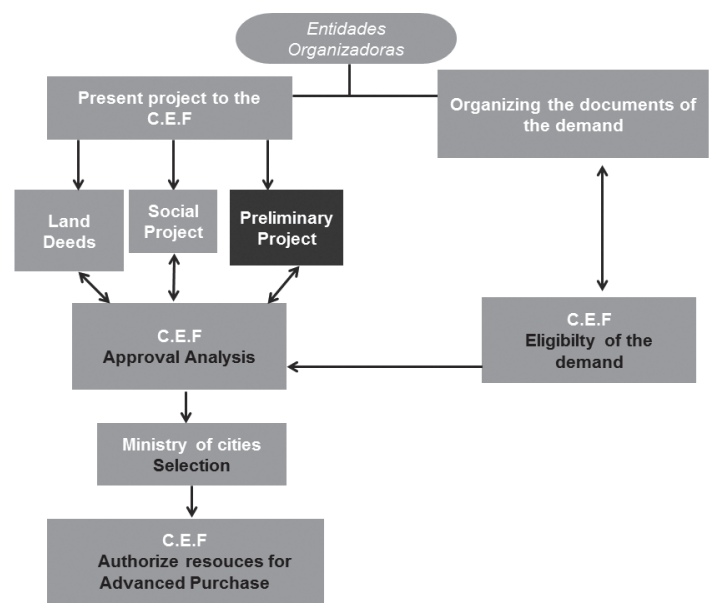

Source: Produced by Patricia Maria de Jesus and Danielle de Assis Pinheiro.
37 We are grateful for this suggestion provided by Luciana O. Royer. 
Figure 1 presents the operational flow of the Entidades modality, from the presentation of the CEF projects through to approval of the resources for the Advance Land Purchase. It also demonstrates the comings and goings of the stages between the social housing movements and the Caixa Econômica Federal. We should herein emphasize the fairly frequent complaint among leaders and their peers that time and energy, essential for improving the important process of forming their grassroots, are drained by the endless bureaucracy.

Figure 2: Flowchart of the Preliminary Project within the Minha Casa Minha Vida Entidades Program

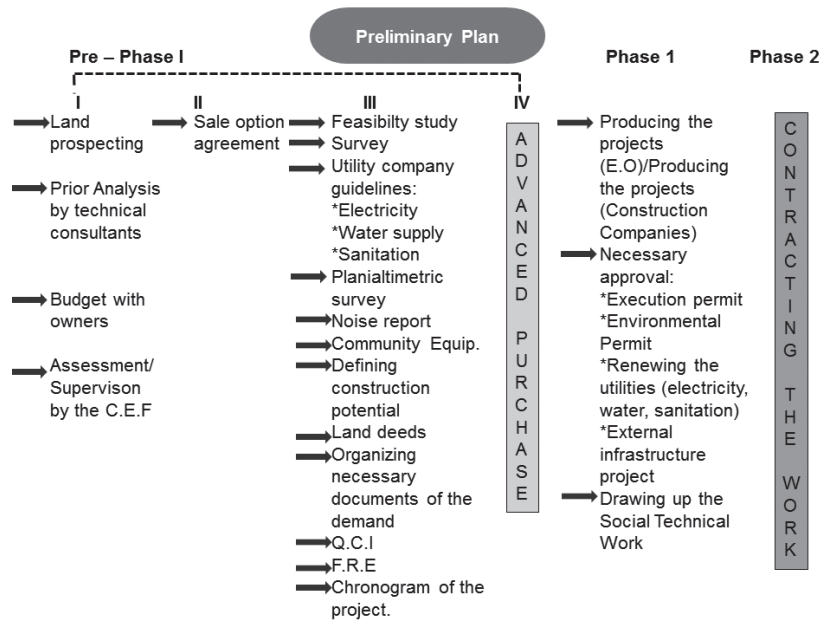

Source: Produced by Patricia Maria de Jesus and Danielle de Assis Pinheiro.

Figure 2 was produced after we confirmed the absence in the brochures, newsletters and Caixa Econômica Federal and Ministry of Cities manuals of a process emphatically described by those we interviewed during this analysis as the "Pre-Phase 1". Nevertheless, understanding it, besides resolving many questions, also revealed the limitations and bias involved in producing this material, since they only presented the Advanced Land Purchase and Phase 1 (preparation and approval of projects) and 2 (contracting the construction), as if there were nothing beforehand. They also only include the stages between the Entidades Organizadoras and the federal government, thus disregarding the procedures between these groups and other levels of government, including the city councils and state government bodies.

On observation of the figure we may observe how approval of a project within the Entidades modality of the Minha Casa Minha Vida Program functions. We would state that with the exception of certain cases, depending on the characteristics of the land, the size of the project, the building scheme, etc., a project may be exempt from approval in a particular department/specific organ. We therefore consider the figure as an "average" example of what needs to be approved by all of them.

\section{FINAL CONSIDERATIONS}

The fact that the Minha Casa Minha Vida Program contained a specific modality intended for non-profit entities would appear to suggest that within its formulation, there should have been a place for the social housing movements, represented by 
the four national entities. However, we defend the thesis herein that not only is this untrue, but also that the existence of this modality only became accepted through the relentless pressure of that particular group, which did not necessarily signify that it saw many of its demands attended, since we have seen that the modality is a set of adaptations for a program originally produced for another public, with divergent interests to its own. In addition, the non-profit entities within the program make up a myriad of organizations which are also quite diverse, and not always aligned with the proposals of the social housing movements, i.e., the four national entities only demanded a fraction of the program that would attend them. But this portion of the program that attended them (and other housing movements), also serves groups and organizations often unrelated to the discussion and that they insist on guiding.

For these same reasons, the self-management emphatically defended by the social housing movements in the past, and held as a foundational argument for the demands of the Entidades modality is no consensus for its operationalization, not even among some of the social housing movements, perhaps among other types of Entidades Organizadoras. And thus it is that one of the construction schemes accepted by Minha Casa Minha Vida Entidades is the global construction contract, in which a construction company takes responsibility for all the work, while the Entidade Organizadora is left to designate the group of beneficiary families and administrate the resources passed on to them by the federal government.

Thus, on examining the projects of the Minha Casa Minha Vida Entidades Program in São Paulo, and the metropolitan municipalities of Suzano, Guarulhos and Taboão da Serra there are "honourable"38 experiences as well as "dishonourable" experiences. In the dishonourable experiences, the houses do not necessarily possess the quality heralded and desired by the social housing movements. Furthermore, the distortion of the concept of self-management brings into question the justification for the existence of the modality (based on the participation and organization of the beneficiary families throughout all the processes). The achievement of these groups is undermined when compared to "real estate" or when certain construction companies act as "surrogates" from some movements to access the resouces of the program.

However, the honourable experiences should not be viewed as exceptions. It is necessary for their true potential to be seen and therefore, that they become widely disseminated, discussed and also improved. There are many positive points, among which the quality of the housing units (better, larger and cheaper than those produced by the construction companies) is just one, but which synthesizes many others: the full participation of the beneficiary families in the processes (from the preparation of the project through to the construction work), the freedom to propose, develop, select and manage projects appropriate to their needs, the knowledge and penetration of/into institutional spaces that potentialize the improvement of the political life of the people involved, the cooperation with all the surrounding elements of the projetcs so as to fulfil the pre-estabished demands in these locations and any future problems that will arise because of the project.

[...] The MCMV-E represented gains for the entities in terms of human, material and symbolic resources. In certain cases, the regular influx of resources allowed the entities to contract professionals to work alongside volunteer frameworks, as well as to expand the organizational repertoire when inserting entities into a management logic, which
38 In reference to the expression by Chico de Oliveira used by Rizek et al. (2014). 
Patrícia Maria de Jesus graduated in Geography at the Universidade Estadual Paulista "Júlio de Mesquita Filho" (UNESP); she completed her Master and Doctorate degree in Human Geography at the Universidade de São Paulo (USP); she is currently completing her Postdoctoral studies in Planejamento $e$ Gestão do Território at the Universidade Federal do $A B C$ (UFABC)

E-mail: eupatimj@yahoo. com.br.

Article received on $8^{\text {th }}$ Abril 2016 and approved for publication on $29^{\text {th }}$ June 2016. implied a broadening of the range of actors with whom they necessarily had to dialogue and negotiate. For some, this has resulted in a rich learning curve (TATAGIBA, 2015, p. 17 , author's translation).

In other words, this concerns the effective achievement of homeownership, "although not only that," through the actions of the social housing movements within such an unfavorable environment as the Minha Casa Minha Vida Program.

Ultimately, this concerns the articulation of the working classes within this environment of dispute, and how it is possible to transform it (albeit with many obstacles) and appropriate it. For this reason, it is not acceptable to "relinquish" the modality, or "succumb" to its weaknesses, contradictions, limits. On the contrary, it is necessary to insist on it; although on its own this is not enough. It is imperative that the complex relationship between these groups and the bureaucracy be changed and improved.

With regard to the land issue, in our view, there is no Advanced Land Purchase that may solve (in fact) the issue of access to land, since the existence of the instrument does not exempt the social housing movements from competing for the land (in absolutely unequal conditions) on the market, with the construction companies. Only appropriate policies for reserving areas within the urban fabric of the municipalities for the construction of social housing can change the perversity of this logic. However, we should not lose sight of the fact that access to land has been a problem for centuries in Brazilian society and not of the Entidades modality, but the fact that this modality is an appendix of PMCMV without a proper design that promotes the production of self-management potentiates the problem still further.

Finally, it will be down to the question of whether the Entidades modality of the Minha Casa Minha Vida Program is not in fact a real possibility for expanding the limits of this public policy, in which popular groups participate within it not only as beneficiaries, but as its proponents and implementers. However, in order for this to occur, their proposals should not be heeded by policymakers at some future date, but should rather be a presupposed part of it, committed and without prejudice.

\section{REFERENCES}

ARANTES, P.; FIX, M. Como o Governo Lula pretende resolver o problema da habitação. Alguns comentários sobre o pacote habitacional Minha Casa Minha Vida. Correio da Cidadania, São Caetano do Sul, 543, 30 jul. 2009. Available at: <http://www.correiocidadania.com.br/index.php?option=com_content $\& v i e w=$ article $\&$ id $=3580$ :pcthabitacional310709\&catid=66:pacote-habitacional\&Itemid=171>. Accessed on: $5^{\text {th }}$ August 2016.

BRASIL. Ministério das Cidades. Minha Casa Minha Vida Entidades (Cartilha) s/d. Available at: <http://www.cidades.gov.br/>. Accessed on: 23 $3^{\text {rd }}$ April 2009.

Programa Minha Casa Minha Vida (Caderno) s/d. Available at: <http://www. cidades.gov.br/>. Accessed on: 28 $8^{\text {th }}$ Oct. 2013.

CAIXA ECONÔMICA FEDERAL. Minha Casa Minha Vida Entidades. Pessoa jurídica Compra Antecipada de Terreno (Cartilha) s/d. Available at: <http://www.caixa.gov.br/>. Accessed on: 15 ${ }^{\text {th }}$ April 2014.

Programa Minha Casa Minha Vida Entidades - Recursos FDS (Manual). s/d. Avail- 
able at: <http://www.caixa.gov.br/>. Accessed on: $15^{\text {th }}$ April 2014.

CARDOSO, A. L.; ARAGÃO, T. A. Do fim do BNH ao Programa Minha Casa Vida: 25 anos da política habitacional no Brasil. In: CARDOSO, A. L. (Org.). O Programa Minha Casa Minha Vida e seus efeitos territoriais. Rio de Janeiro: Letra Capital; Observatório das Metrópoles, 2013. p. 17-65.

_; ______; ARAÚJO, F. S. Habitação de interesse social: política ou mercado? Reflexos sobre a construção do espaço metropolitano. In: ENCONTRO NACIONAL DA ANPUR, 14., 2011, Rio de Janeiro. Anais do XIV ENAnpur. Rio de Janeiro: ANPUR. 2011. Available at: <http://unuhospedagem.com.br/revista/rbeur/index.php/ anais/article/view/3082/3017>. Accessed on: $5^{\text {Th }}$ August 2016.

CHESNAIS, F. O capital portador de juros: acumulação, internacionalização, efeitos econômicos e políticos. In: (Org.). A finança mundializada. Boitempo Editorial. 2005.

FIX, M. Financeirização e transformaçôes recentes no circuito imobiliário no Brasil. 2011. Thesis (Doctorate in Economy) - Instituto de Economia, Universidade Estadual de Campinas, Campinas, 2011.

HARVEY, D. A condição pós-moderna. São Paulo: Edições Loyola, 1989.

LAGO, L. C. Autogestão da moradia na superação da periferia urbana: conflitos e avanços. e-metropolis, ano 2, n. 5, p. 6-12, jun. 2011. Available at: <http://www.observatoriodasmetropoles.net/download/emetropolis_n05.pdf>. Accessed on: $5^{\text {th }}$ August 2016.

MARICATO, E. O “Minha Casa” é um avanço, mas segregação urbana fica intocada. Carta Maior, São Paulo, 27 maio 2009. Available at: <http://cartamaior.com.br/?/Editoria/ Politica/O-Minha-Casa-e-um-avanco-mas-segregacao-urbana-fica-intocada/4/15160>. Accessed on: $5^{\text {th }}$ August 2016.

MINEIRO, E.; RODRIGUES, E. Do Crédito Solidário ao MCMV Entidades: uma história em construção. LAGO, L. C. (Org.). Autogestão habitacional no Brasil: utopias e contradiçóes. Rio de Janeiro: Letra Capital; Observatório das Metrópoles, 2012. p. $19-48$.

RIZEK, C. S. et al. A Inserção Urbana através da Produção do MCMV-Entidades no Estado de São Paulo: Abordagem Etnográfica de Casos Selecionados. In: ENCONTRO DA ANPARQ, 3., 2014, São Paulo. Anais do III ENAnparq. São Paulo: ANPARQ, 2014.

et al. Viver na cidade, fazer cidade, esperar cidade. Inserções urbanas e o PMCMV-Entidades: incursóes etnográficas. In: SANTO AMORE, C.; SHIMBO, L. Z.; RUfinO, M. B. C. (Org.) Minha Casa... E a Cidade? Avaliação do Programa Minha Casa Minha Vida em seis estados brasileiros. Rio de Janeiro: Letra Capital, 2015. p. 289-322.

RODRIGUES. E. L. A estratégia fundiária dos movimentos populares na produção autogestionária da moradia. 2013. Dissertation (Master in Architecture and Urbanism) Faculdade de Arquitetura e Urbanismo, Universidade de São Paulo, São Paulo, 2013.

ROLNIK, R. (Org.). Como produzir moradia bem localizada com recursos do Programa Minha Casa Minha Vida? Implementando os instrumentos do Estatuto da Cidade! Brasília: Ministério das Cidades, 2010.

; NAKANO, K. As armadilhas do pacote habitacional. Le Monde Diplomatique Brasil, São Paulo, ano 2, n. 20, p. 4-5, 5 mar. 2009. Available at: <http://www.diplomatique.org.br/artigo.php?id=461>. Accessed on: $5^{\text {th }}$ August 2016.

ROYER, L. O. Financeirizaçâo da política habitacional: limites e perspectivas. 2009. Thesis (Doutorate in Architecture and Urbanism) - Faculdade de Arquitetura e Urbanismo, Universidade de São Paulo, São Paulo, 2009.

SHIMBO, L. Z. Habitação social, habitação de mercado: a confluência entre estado, empresas construtoras e capital financeiro. 2010. Thesis (Doutorate in Architecture and 
THE INCLUSION AND ACCESS OF SOCIAL HOUSING MOVEMENTS...

Urbanism) - Instituto de Arquitetura e Urbanismo, Universidade de São Paulo, São Carlos, 2010.

TATagiba, L. (Coord.). Avaliação do Programa Minha Casa, Minha Vida - Entidades. O desafio da participação dos beneficiários. Chamada MCTI/CNPq/MCIDADES n ${ }^{\circ}$ 11/2012. Relatório Final de Pesquisa. Campinas: Nepac/Unicamp, 2015.

\section{LEGISLATION}

BRASIL. Law no 11.977, on 7/7/2009. Regarding the Minha Casa, Minha Vida ProgramPMCMV and the land regulation of settlements located in urban areas.

Law no 12.424, on 16/6/2011. Regarding the Minha Casa, Minha Vida ProgramPMCMV 2 and the land regulation of settlements located in urban areas.

. Bill 4.960/2016. Changing Law $n^{\circ} 11.977$, on 7th July 2009, regarding the a Minha

Casa, Minha Vida Program - PMCMV and the land regulation of settlements located in urban areas.

BRASIL. Ministry of Cities. Interministerial Bill no 96, on 30/3/2016.

BRASIL. Ministry of Cities. Trustee Concillor of the Social Development Fund. Resolution $n^{\circ} 141$, on 10/6/2009.

Resolution $n^{\circ} 143$, on 26/11/2009.

Resolution $n^{\circ} 182$, on 18/8/2011.

Resolution $n^{\circ} 183$, on 10/11/2011.

Resolution $n^{\circ} 190$, on $7 / 8 / 2012$.

. Resolution $n^{\circ} 193$, on 30/10/2012.

. Resolution $n^{\circ} 194$, on 12/12/2012.

Resolution $n^{\circ}$ 200, on 5/8/2014. 